\title{
Actions of Parathyroid Hormone in the Vitamin D-deficient $\operatorname{Dog} *$
}

\author{
Robert L. Ney $\dagger$ William Y. W. Au, $\ddagger$ Gerald Kelly, I. Radde, $\S$ and \\ FREDERIC C. BARTTER \| \\ (From the Clinical Endocrinology Branch of the National Heart Institute, and the Clinical \\ Pathology Clinical Center, National Institutes of Health, Bethesda, Md.)
}

The effects of parathyroid hormone on bone and kidney have been well documented (1). It has not been settled, however, whether the hormone exerts similar actions in the rachitic animal. Rasmussen and associates have found that parathyroid hormone lowers the serum phosphorus in the vitamin D-depleted rat (2). Harrison and Harrison, however, observed that vitamin $\mathrm{D}$-depleted rats did not respond to parathyroid hormone with either an increase in urinary phosphorus or a decrease in serum phosphorus (3). In both of these studies, the serum calcium of vitamin D-depleted rats failed to increase after an injection of parathyroid extract at a dosage that elevated the serum calcium of control animals $(2,3)$. In contrast, in recent studies by Toverud $(4,5)$, it was found that the serum calcium decreases after parathyroidectomy in vitamin $\mathrm{D}$-depleted rats; an increase in serum calcium was observed after the administration of parathyroid extract to the vitamin D-depleted, parathyroidectomized animals. Earlier investigations (6) had shown that parathyroid extract could increase the serum calcium in the rachitic dog, although the effect was not as great as that in normal dogs and bore no consistent relationship to dosage. However, the rachitic dogs were not parathyroidectomized before the administration of parathyroid extract. It was therefore possible that the animals were

* Submitted for publication May 24, 1965; accepted August 31, 1965.

$\dagger$ Present address: Vanderbilt University School of Medicine, Department of Medicine, Nashville, Tenn.

$¥$ Present address: University of Rochester School of Dentistry and Medicine, Department of Medicine, Rochester, N. Y.

$\S$ Present address: Hospital for Sick Children, Research Unit, Toronto 2, Ontario, Canada.

$\|$ Address requests for reprints to Dr. Frederic C. Bartter, Chief, Clinical Endocrinology Branch, National Heart Institute, Bethesda, Md. 20014. under the influence of large quantities of endogenous parathyroid hormone, which obscured the action of exogenous extract. In the present studies, serial observations have been made of calcium and phosphorus metabolism and of hydroxyproline excretion in the vitamin D-depleted dog. Animals were studied before and after parathyroidectomy and with the subsequent administration of parathyroid extract.

\section{Methods}

Seventeen mongrel pups were placed on a rachitogenic diet at the time of weaning. The daily diet for each animal contained $400 \mathrm{~g}$ of oatmeal, $100 \mathrm{~g}$ of powdered skimmed milk, $7 \mathrm{~g}$ of brewer's yeast, $3.5 \mathrm{~g}$ of $\mathrm{NaCl}, 10 \mathrm{mg}$ of vitamin $\mathrm{C}, 1,000 \mathrm{U}$ of vitamin $\mathrm{A}$, and $15 \mathrm{ml}$ of peanut oil. The diet provided $200 \mathrm{mg}$ of calcium and $800 \mathrm{mg}$ of phosphorus daily. Five control pups of comparable age were studied while on an identical diet; these animals also received $500 \mathrm{U}$ of vitamin $\mathrm{D}_{\mathbf{2}}$ daily. Three additional control pups were maintained on a constant diet of standard dog food, providing $500 \mathrm{mg}$ of calcium and $1,000 \mathrm{mg}$ of phosphorus daily. All animals were kept in a room protected from sunlight, illuminated by an ultraviolet-free light source.

Phosphorus and inulin clearances were measured in 14 rachitic dogs while they were on diet alone. The studies were repeated in 12 animals 3 to 6 hours after thyroparathyroidectomy, and in six of these, clearance studies were performed again with the subsequent infusion of parathyroid extract. Phosphorus clearances were measured in six control dogs while on constant diet alone, and in three of these inulin clearance was also measured. Animals were fasted 16 hours before the studies. The anesthesia employed was $1 \%$ alpha chloralose in $0.9 \% \mathrm{NaCl}$. Inulin and phosphorus clearance studies were performed as described previously (7). Each clearance period was 20 minutes in duration, and blood was obtained in the middle of the period. Whenever possible, data were obtained for three or more successive periods at each phase of the study.

Serum and urinary phosphorus as inorganic phosphate were measured by the method of Fiske and SubbaRow (8). Serum and urinary calcium were determined with the flame photometer (9). Urinary hydroxyproline was 
TABLE I

Comparison of data for normal and rachitic dogs

\begin{tabular}{|c|c|c|c|}
\hline & $\begin{array}{c}\text { Normal } \\
\text { Mean } \pm \text { SEM }\end{array}$ & $\begin{array}{c}\text { Rickets } \\
\text { Mean } \pm \text { SEM }\end{array}$ & $p$ value \\
\hline$\underset{U / 100 \mathrm{ml}}{\text { Serum vitamin D }}$ & $472 \underset{(7)^{*}}{ \pm} 55$ & $\begin{array}{l}<25 \\
(7)\end{array}$ & $<0.001$ \\
\hline $\begin{array}{l}\text { Serum alkaline phosphatase } \\
\text { King-Armstrong units }\end{array}$ & $13 \underset{(4)}{ \pm} 2$ & $47_{(9)}^{ \pm} 7$ & $<0.02$ \\
\hline $\begin{array}{l}\text { Serum calcium } \\
\mathrm{mg} / 100 \mathrm{ml}\end{array}$ & $\begin{array}{l}11.7 \text { (6) } \\
\text { 士 }\end{array}$ & $\underset{(12)}{8.5} 0.5$ & $<0.001$ \\
\hline $\begin{array}{l}\text { Serum phosphorus } \\
\mathrm{mg} / 100 \mathrm{ml}\end{array}$ & $\underset{(8)}{8.3} 0.5$ & $\underset{(14)}{4.7} 0.2$ & $<0.001$ \\
\hline $\begin{array}{l}\text { Urinary phosphorus } \\
\mu \mathrm{g} / \text { minute }\end{array}$ & $159 \underset{(6)}{ \pm 71}$ & $207 \underset{(14)}{ \pm} 26$ & $<0.50$ \\
\hline $\begin{array}{l}\text { Clearance phosphorus } \\
\text { ml/minute }\end{array}$ & $\underset{(6)}{2.2 \pm} 0.4$ & $\underset{(14)}{4.6 \pm 0} 0.6$ & $<0.02$ \\
\hline $\begin{array}{l}\text { Clearance inulin } \\
\mathrm{ml} / \mathrm{minute}\end{array}$ & $43_{(3)}^{ \pm} 7$ & $34_{(8)}^{ \pm} 5$ & $<0.40$ \\
\hline $\begin{array}{l}\text { Urinary hydroxyproline } \\
\mu g / \text { minute }\end{array}$ & $32_{(5)}^{ \pm} 3$ & $48 \underset{(8)}{ \pm} 6$ & $<0.05$ \\
\hline
\end{tabular}

* The number of animals is indicated in parentheses.

measured by the method of Prockop and Udenfriend (10). The coefficient of variation was $2.2,3.0$, and $2.3 \%$ for the calcium, phosphorus, and hydroxyproline methods, respectively (11). Inulin was measured in blood and urine by the method of Walser, Davidson, and Orloff (12). Serum alkaline phosphatase was measured by the method of King and Armstrong (13). Serum vitamin D assays ${ }^{1}$ were performed in the rachitic rat according to the method of Shue, Friedman, and Tolle (14). This method is capable of detecting as little as $1 \mathrm{U}$ of vitamin D. Since the maximal amount of serum that was administered to a rat was $4 \mathrm{ml}$, the lower limit of sensitivity of the assay was $25 \mathrm{U}$ per $100 \mathrm{ml}$ of serum.

When the data for the rachitic pups were compared with those for the control pups, the significance of differences between the two groups was determined by the Student $t$ test (15). When rachitic animals were studied serially, e.g., before and after parathyroidectomy, the observations for each animal were paired. The $t$ test was then performed on the paired observations for the group of animals.

\section{Results}

Comparison of rachitic and control animals. After 8 to 12 weeks on the rachitogenic diet, all 17 pups demonstrated severe clinical rickets, with characteristic physical findings in the extremities, skull, and ribs. Rickets was documented radiologically, and in a few instances by histological examination of bone. No vitamin D activity was detectable in the serum of the rachitic animals, whereas the mean activity in the serum of control

1 The authors are indebted to Mr. Walter Hooper and Mr. Glen Shue of the U. S. Food and Drug Administration, Washington, D. C., for the performance of the vitamin $\mathrm{D}$ assays. animals was $420 \mathrm{U}$ per $100 \mathrm{ml}$ (Table I). Serum alkaline phosphatase was markedly elevated in the rachitic pups (Table I).

Abnormalities in phosphorus metabolism in the rachitic animals are apparent from the data listed in Table I. The rachitic dogs demonstrated significant hypophosphatemia. Although mean urinary phosphorus for the rachitic animals was greater than that for the controls, the difference was not significant. Renal phosphorus clearance for the rachitic animals, however, was more than twice that for the controls. Since glomerular filtration rate (measured with inulin) was not different for the two groups, the greater phosphorus clearance of the rachitic dogs resulted from a decrease of tubular conservation of phosphorus.

Phosphorus metabolism in rachitic dogs after parathyroidectomy and with the subsequent administration of parathyroid extract. One to seven days after the base-line clearance studies, 12 of the rachitic dogs underwent thyroparathyroidectomy. Between 3 and 6 hours after surgery, clearances were repeated. These clearances were performed at about the same time of day as the base-line studies. Urinary phosphorus and phosphorus clearance had decreased strikingly in every animal ( $\mathrm{Ta}$ ble II). These changes could not be attributed to variations in glomerular filtration rate (Table III). Serum phosphorus rose in eight of the animals, the mean for the group increasing from 4.7 to $5.5 \mathrm{mg}$ per $100 \mathrm{ml}(\mathrm{p} \leq 0.05)$. In three additional rachitic animals, serum phosphorus was determined before and 24 hours after parathyroidectomy; clearances were not performed at these times. Serum phosphorus in these animals was $4.2,5.7$, and $4.9 \mathrm{mg}$ per $100 \mathrm{ml}$ before parathyroidectomy, and had increased to $5.8,9.1$, and $7.6 \mathrm{mg}$ per $100 \mathrm{ml}$, respectively, 24 hours after surgery. Thus, in rachitic animals greater increases in serum phosphorus were observed with time after parathyroidectomy. These findings indicate that the hypophosphatemia and the decreased renal tubular conservation of phosphorus of the rachitic dogs are dependent on parathyroid activity.

Four rachitic animals subsequently received 2-hour infusions of parathyroid extract ${ }^{2}$ at a rate of $10 \mathrm{U}$ per minute. Two additional animals re-

2 Generously supplied by Dr. G. Irwin of the Eli Lilly Company, Indianapolis, Ind. 


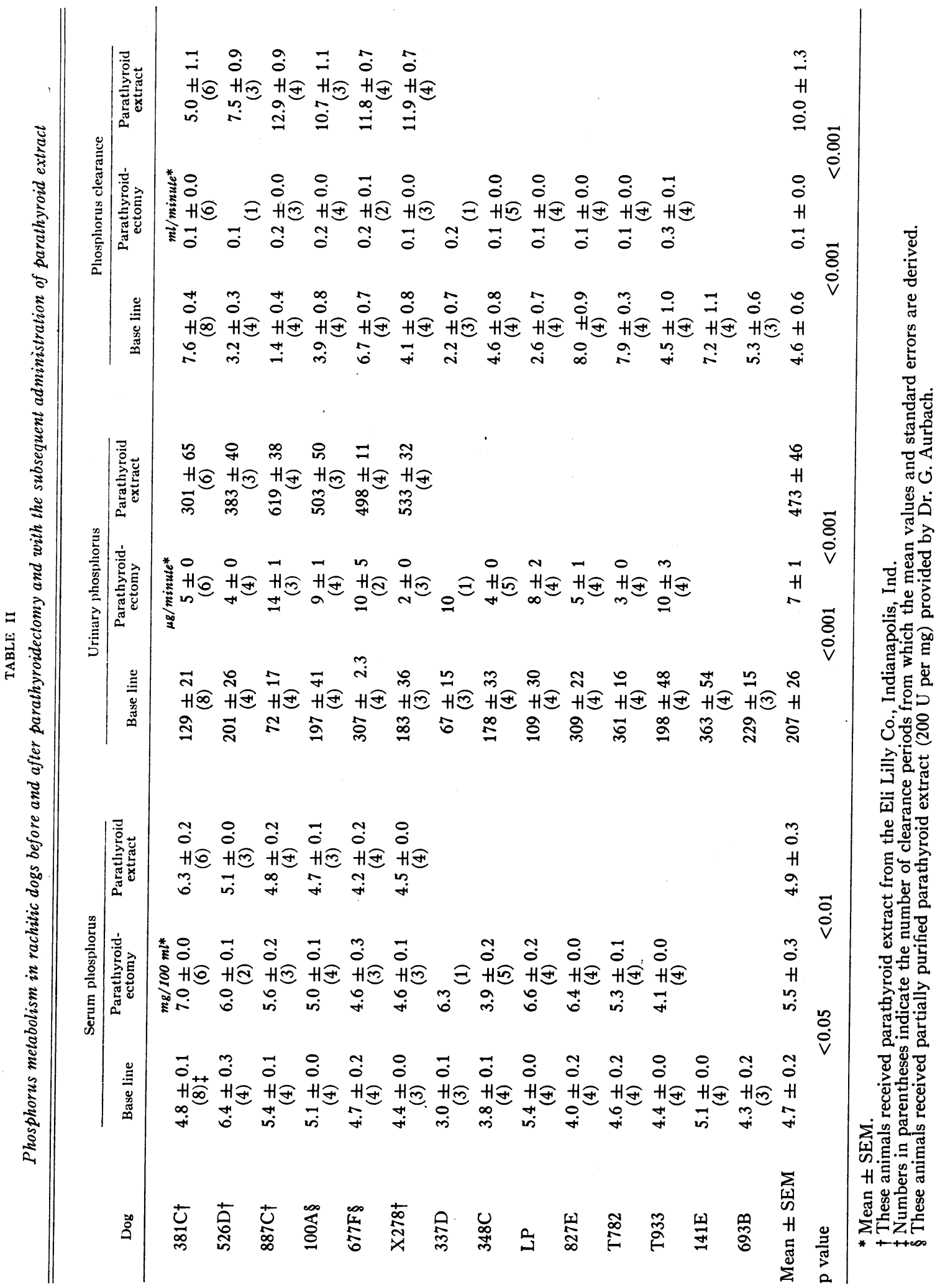


TABLE III

Inulin clearances before and after parathyroidectomy and with the subsequent administration of parathyroid extract

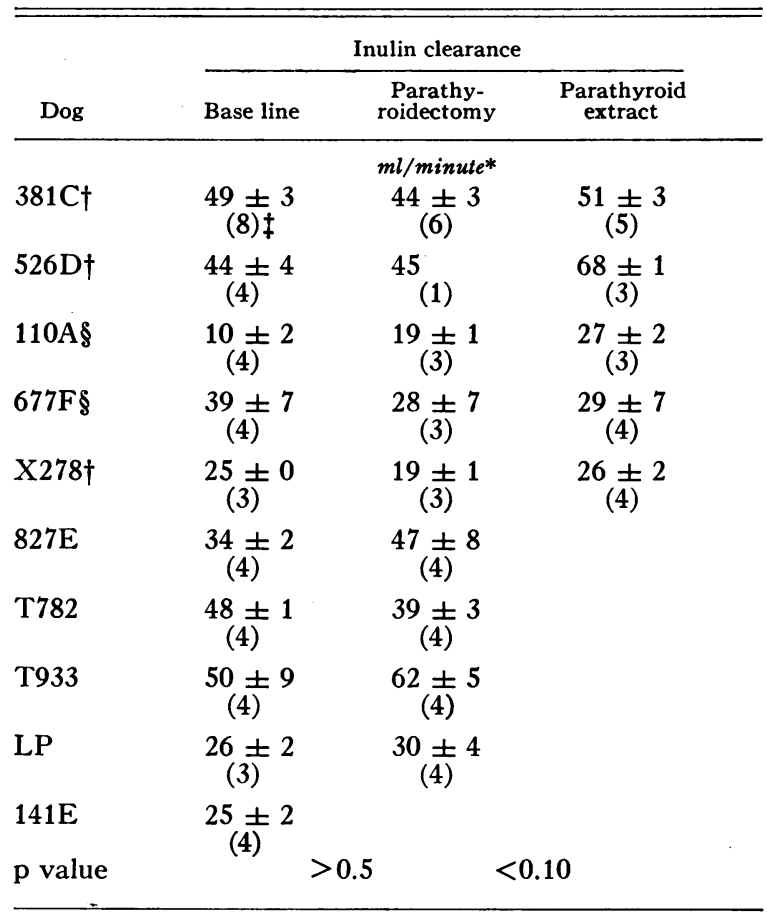

$*$ Mean \pm SEM.

$\dagger$ These animals received parathyroid extract from the Eli Lilly Co.

$\ddagger$ The number of clearance periods is indicated in parentheses.

$\S$ These animals received parathyroid extract (200 U per $\mathrm{mg}$ ) prepared by Dr. G. Aurbach.

ceived a more purified parathyroid extract ${ }^{3}$ at a rate of $5 \mathrm{U}$ per minute (Tables II and III, dogs $100 \mathrm{~A}$ and $677 \mathrm{~F}$ ). Marked increases were observed in urinary phosphorus and in phosphorus clearance in every animal. In the five dogs in which the measurement was made, there was a tendency for the inulin clearance to increase $(p<$ 0.10 , Table III). Therefore, although endogenous parathyroid hormone had maintained phosphaturia through a tubular effect in the vitamin D-deficient animals (see above), the phosphaturia resulting from exogenous extract may have been partly due to increases in filtered phosphorus.

Calcium metabolism in rachitic dogs after parathyroidectomy and with the subsequent administration of parathyroid extract. Serum calcium in

${ }^{3}$ Parathyroid extract with a potency of $200 \mathrm{U}$ per $\mathrm{mg}$ was kindly provided by Dr. G. Aurbach. The methods of preparation of this extract have been previously published (16). the rachitic dogs was lower than that of controls (mean values, 8.5 vs. $11.7 \mathrm{mg}$ per $100 \mathrm{ml}$, Table I). After parathyroidectomy, however, further decreases in serum calcium were noted in the vitamin D-deficient animals within 3 to 6 hours in 11 of 12 instances (Table IV), a change that was highly significant $(p<0.001)$. In the three additional rachitic animals, serum calcium was 10.4 , 10.2 , and $8.5 \mathrm{mg}$ per $100 \mathrm{ml}$ before parathyroidectomy, and it had decreased to $4.5,5.6$, and $4.2 \mathrm{mg}$ per $100 \mathrm{ml}$, respectively, 24 hours after surgery; clearances were not performed at these times. Thus, in rachitic animals after parathyroidectomy, greater decreases in serum calcium were observed with time. These findings suggest that endogenous parathyroid hormone was exerting a calciummobilizing action in the vitamin D-depleted dog.

With the administration of parathyroid extract to the rachitic, parathyroidectomized dogs, serum calcium increased in every instance $(\mathrm{p}<0.01$, Table IV). Urinary calcium was determined at the different phases of the study for several of the animals (Table IV). The fall in serum calcium after parathyroidectomy was not accompanied by a consistent increase in urinary calcium; the means for the group before and after parathyroidectomy did not differ significantly $(p \geq 0.50)$. Similarly, the rise in serum calcium with the administration of parathyroid extract was not accompanied by a significant decrease in urinary calcium $(p<0.40)$. These findings indicate that the changes in serum calcium were not a reflection of changes in urinary calcium.

Urinary hydroxyproline in rachitic dogs before and after parathyroidectomy and with the subsequent administration of parathyroid extract. In the rachitic dogs, urinary hydroxyproline was significantly greater than that of the controls (Table I). After parathyroidectomy, hydroxyproline peptides decreased in seven of eight rachitic animals (Table V), a finding that suggested that the initial high values in these animals resulted from excess of endogenous parathyroid hormone. When parathyroid extract was administered in six of the rachitic parathyroidectomized dogs, urinary hydroxyproline increased in every instance.

\section{Discussion}

The present studies indicate that the hypophosphatemia of rachitic dogs is associated with, and is 
perhaps a consequence of, decreased renal tubular conservation of phosphorus. That these modifications in phosphorus metabolism are not the direct result of a deficiency of vitamin $\mathrm{D}$ is evident from the findings after parathyroidectomy. As urinary phosphorus and phosphorus clearance fell strikingly, it is clear that the renal tubules were able to conserve phosphorus despite deficiency of vitamin D. Furthermore, serum phosphorus increased progressively with time after parathyroidectomy. These data also indicate that the renal tubules of the vitamin $\mathrm{D}$-deficient dogs were responsive to endogenous parathyroid hormone, and that the preoperative hypophosphatemia and increased phosphorus clearance were dependent on the tubular effect of the hormone. It has been suggested that impairment in calcium absorption is the primary physiological abnormality in the rachitic animal (17). It may be postulated that the resulting hypocalcemia stimulates parathyroid activity, leading to the observed abnormalities in phosphorus metabolism.

The present studies also suggest that parathyroid hormone influences the mobilization of bone mineral in the vitamin D-deficient dog. After parathyroidectomy, serum calcium fell significantly, indicating that endogenous hormone was exerting a calcium-mobilizing effect. The serum calcium had decreased further 24 hours after parathyroidectomy. The administration of parathyroid extract increased the serum calcium in each rachitic parathyroidectomized animal. The changes

TABLE IV

Calcium metabolism in rachitic dogs before and after parathyroidectomy and with the subsequent administration of parathyroid extract

\begin{tabular}{|c|c|c|c|c|c|c|}
\hline \multirow[b]{2}{*}{ Dog } & \multicolumn{3}{|c|}{ Serum calcium } & \multicolumn{3}{|c|}{ Urinary calcium } \\
\hline & Base line & $\begin{array}{l}\text { Parathyroid- } \\
\text { ectomy }\end{array}$ & $\begin{array}{c}\text { Parathyroid } \\
\text { extract }\end{array}$ & Base line & $\begin{array}{l}\text { Parathyroid- } \\
\text { ectomy }\end{array}$ & $\begin{array}{c}\text { Parathyroid } \\
\text { extract }\end{array}$ \\
\hline & \multicolumn{3}{|c|}{$m g / 100 m l^{*}$} & \multicolumn{3}{|c|}{$\mu g / m i n u t e^{*}$} \\
\hline $381 \mathrm{C} \dagger$ & $\begin{array}{l}9.5 \pm 0.3 \\
(2) \ddagger\end{array}$ & $\begin{array}{c}5.3 \pm \\
(5)\end{array}$ & $6.4 \underset{(6)}{ \pm} 0.3$ & & & \\
\hline $526 \mathrm{D} \dagger$ & $\begin{array}{l}7.2 \pm 0.1 \\
(2)\end{array}$ & $6.7 \underset{(2)}{ \pm} 0.0$ & 7.3 (1) & & & \\
\hline $887 \mathrm{C} \dagger$ & $\begin{array}{l}6.5 \pm 0.3 \\
(2)\end{array}$ & $5.1 \pm \underset{(2)}{ \pm} 0.2$ & $5.7 \underset{(2)}{ \pm} 0.8$ & & & \\
\hline $100 \mathrm{~A} \S$ & $\begin{array}{l}9.7 \pm 0.2 \\
(2)\end{array}$ & $7.8 \underset{\text { (2) }}{ \pm} 0.1$ & $9.7 \underset{(2)}{ \pm} 0.0$ & $32 \underset{(2)}{ \pm} 13$ & $35 \underset{(2)}{ \pm} 6$ & $43 \underset{(2)}{ \pm} 17$ \\
\hline $677 \mathrm{~F} \S$ & $\begin{array}{l}8.1 \pm 0.1 \\
\quad(2)\end{array}$ & $6.4 \underset{(3)}{ \pm} 0.1$ & $7.6 \underset{(3)}{ \pm} 0.0$ & $83 \underset{(2)}{ \pm} 37$ & $29 \pm \frac{ \pm}{(3)} 7$ & $94 \underset{(2)}{ \pm} 21$ \\
\hline$x 278 \dagger$ & $\begin{array}{l}7.8 \pm 0.1 \\
(2)\end{array}$ & ${ }_{(2)}^{6.2 \pm 0.1}$ & $7.9 \underset{(2)}{ \pm} 0.2$ & $56 \underset{(2)}{ \pm} 7$ & 37 (2) 3 & $59 \underset{(2)}{ \pm} 0$ \\
\hline $337 \mathrm{D}$ & $\begin{array}{l}6.0 \pm 0.1 \\
(2)\end{array}$ & ${ }^{6.1}$ & & & & \\
\hline $348 \mathrm{C}$ & $\begin{array}{l}8.0 \pm 0.1 \\
(2)\end{array}$ & $7.5 \underset{(2)}{ \pm} 0.1$ & & & & \\
\hline LP & $\begin{array}{c}9.5 \pm 0.5 \\
(2)\end{array}$ & ${ }_{(2)}^{6.3} 0.7$ & & & & \\
\hline $827 \mathrm{E}$ & $\begin{array}{c}10.1 \pm 0.5 \\
(4)\end{array}$ & $7.4 \underset{(4)}{ \pm} 0.1$ & & ${ }_{(2)}^{57} 15$ & $142_{\text {(2) }}^{ \pm} 35$ & \\
\hline T782 & $\begin{array}{c}11.5 \pm 0.6 \\
(4)\end{array}$ & $10.1 \underset{\text { (4) }}{ \pm} 0.7$ & & $161_{(2)}^{ \pm} 35$ & $176 \pm 20$ & \\
\hline T933 & $\begin{array}{l}8.1 \pm 0.7 \\
\quad(4)\end{array}$ & $6.1 \pm$ (4) 0.4 & & $141 \underset{(2)}{ \pm} 18$ & $187_{(2)}^{ \pm} 23$ & \\
\hline Mean & $8.5 \pm 0.5$ & $6.8 \pm 0.4$ & $7.4 \pm 0.6$ & $88 \pm 21$ & $101 \pm 31$ & $65 \pm 15$ \\
\hline$p$ value & \multicolumn{2}{|c|}{$<0.001$} & & \multicolumn{2}{|c|}{$\geq 0.5$} & $<0.40$ \\
\hline
\end{tabular}

* Mean \pm SEM

$\dagger$ These animals received parathyroid extract from the Eli Lilly Co.

¥ Numbers in parentheses indicate the number of consecutive observations from which the mean values and standard errors are derived.

$\S$ These animals received parathyroid extract (200 U per mg) prepared by Dr. G. Aurbach. 
TABLE V

Urinary hydroxyproline before and after parathyroidectomy and with the subsequent administration of parathyroid extract

\begin{tabular}{|c|c|c|c|}
\hline \multirow[b]{2}{*}{ Dog } & \multicolumn{3}{|c|}{ Urinary hydroxyproline } \\
\hline & Base line & $\begin{array}{c}\text { Parathy- } \\
\text { roidectomy }\end{array}$ & $\begin{array}{c}\text { Parathyroid } \\
\text { extract }\end{array}$ \\
\hline & \multicolumn{3}{|c|}{$\mu g /$ minute* } \\
\hline $381 \mathrm{C} \dagger$ & $62 \pm 1$ & $20 \underset{(4)}{ \pm} 4$ & $68 \underset{(4)}{ \pm} 10$ \\
\hline $526 \mathrm{D} \dagger$ & $\underset{(3)}{49} 7$ & $17 \underset{(3)}{ \pm} 6$ & $61 \underset{(3)}{ \pm} 7$ \\
\hline $887 \mathrm{C} \dagger$ & $\underset{(4)}{67}+4$ & $46 \underset{(3)}{ \pm} 3$ & $115 \underset{(4)}{ \pm} 8$ \\
\hline 100A $\$$ & $\underset{(4)}{25}$ 土 3 & $21 \underset{(4)}{ \pm} 2$ & $58 \underset{(4)}{ \pm} 3$ \\
\hline F677§ & $\underset{(4)}{39} 2$ & $23 \underset{(4)}{ \pm} 2$ & $34 \underset{(4)}{ \pm} 6$ \\
\hline$\times 278 \dagger$ & $\begin{array}{c}46 \pm 3 \\
(3)\end{array}$ & $23 \underset{(4)}{ \pm} 2$ & $44 \underset{(4)}{ \pm}$ \\
\hline $827 \mathrm{E}$ & $\underset{(2)}{38}$ 土 1 & $42 \underset{(2)}{ \pm} 6$ & \\
\hline T782 & $\begin{array}{c}59 \pm 6 \\
(2)\end{array}$ & $43 \underset{(2)}{ \pm} 3$ & \\
\hline Mean & $48 \pm 6$ & $29 \pm 4$ & $63 \pm 11$ \\
\hline p value & $\mathrm{p}$ & 0.005 & 0.025 \\
\hline
\end{tabular}

* Mean \pm SEM.

$\dagger$ These animals received parathyroid extract from the Eli Lilly Co.

$\ddagger$ The number of observations is indicated in parentheses. $\$$ These animals received parathyroid extract $(200 \mathrm{U}$ per mg) prepared by Dr. G. Aurbach.

in serum calcium concentration could not be attributed to changes in urinary calcium. Previous studies have shown that parathyroid hormone exerts a direct action on bone $(18,19)$. It has also been shown that the increases in serum calcium observed with the administration of parathyroid extract are largely a reflection of this action on bone (20). It is likely, therefore, that the changes in serum calcium in the rachitic dogs resulted from the action of parathyroid hormone on bone mineral.

The results of the present experiments in the dog confirm the observations of Toverud in the rat $(4,5)$ and indicate that parathyroid hormone is capable of mobilizing bone mineral despite a deficiency of vitamin $\mathrm{D}$. Other investigators $(2,3)$, however, have not observed a decrease in serum calcium after parathyroidectomy in vitamin $\mathrm{D}$-depleted rats. The reason for these varying results is not apparent at present. It may be that the animals that showed no decrease in serum calcium after parathyroidectomy were more completely de- pleted of vitamin $\mathrm{D}$. It is possible that vitamin $\mathrm{D}$ is required for the actions of parathyroid hormone on bone, as has been shown for the action of the hormone on kidney mitochondria (21), but that only minute, perhaps unmeasurable, quantities of the vitamin are required for this effect. In the present studies, antirachitic activity could not be detected in the serum of the rachitic dogs with a bioassay technique (Table I). However, it will be necessary to apply more sensitive and specific methods for measuring vitamin $\mathrm{D}$ in blood and tissues to resolve this question.

Since the rachitic pups demonstrated base-line hypocalcemia, they appeared to be less responsive than normal to the calcium-mobilizing action of endogenous hormone. This may have resulted from a decrease in the quantities of calcium at specific bone sites where the hormone exerts its effect, a possibility previously suggested by Munson, Hirsch, and Tashjian (22). Alternatively, as mentioned above, it may have resulted from a requirement for greater quantities of vitamin $\mathrm{D}$. To assess in a quantitative manner the role of vitamin $\mathrm{D}$ in the responsiveness to the calciummobilizing action of parathyroid hormone, it will be necessary to measure the responses to graded doses of parathyroid extract in animals on graded dosages of vitamin D.

Urinary hydroxyproline decreased after parathyroidectomy in the rachitic dogs and subsequently increased with the administration of parathyroid extract (Table V). Available evidence suggests that urinary hydroxyproline peptides reflect collagen turnover (23). Parathyroid extract has been shown to increase release of hydroxyproline from bone in vitro (24). Recent studies by Walker, Lapiere, and Gross (25) have shown that parathyroid extract stimulates a collagenolytic factor in bone, thereby causing the release of hydroxyproline peptides in vitro (25). It has also been shown that parathyroid extract increases excretion of hydroxyproline in human subjects (26). The present studies suggest that parathyroid hormone influences bone collagen turnover despite a deficiency of vitamin $\mathrm{D}$.

\section{Summary}

Calcium and phosphorus clearances and hydroxyproline excretion were measured in rachitic 
dogs before parathyroidectomy, after parathyroidectomy alone, and with the administration of parathyroid extract after parathyroidectomy. In the rachitic dogs, serum phosphorus was decreased and phosphorus clearance was increased, as compared to controls. After parathyroidectomy of the rachitic animals, urinary phosphorus and phosphorus clearance decreased strikingly, indicating the ability of the renal tubules to conserve phosphorus despite vitamin $\mathrm{D}$ deficiency. These results also showed that endogenous parathyroid hormone was exerting a tubular effect to decrease phosphorus conservation despite a lack of vitamin $\mathrm{D}$, and was responsible for the abnormalities in phosphorus metabolism in the rachitic dogs.

After parathyroidectomy, serum calcium fell in 11 of 12 rachitic animals, and it increased with the subsequent administration of parathyroid extract. These changes could not be attributed to changes in urinary calcium, and they suggested an action of parathyroid hormone on bone. Urinary hydroxyproline decreased after parathyroidectomy and increased with the subsequent administration of parathyroid extract, suggesting an action of parathyroid hormone on collagen metabolism in the vitamin $\mathrm{D}$-deficient animals.

\section{References}

1. Rasmussen, H. Parathyroid hormone, nature and mechanism of action. Amer. J. Med. 1961, 30, 112.

2. Rasmussen, H., H. DeLuca, C. Arnaud, C. Hawker, and $M$. von Stedingk. The relationship between vitamin $\mathrm{D}$ and parathyroid hormone. J. clin. Invest. $1963,42,1940$.

3. Harrison, H. E., and H. C. Harrison. The interaction of vitamin $\mathrm{D}$ and parathyroid hormone on calcium phosphorus and magnesium homeostasis in the rat. Metabolism 1964, 13, 952.

4. Toverud, S. U. in The Transfer of Calcium and Strontium across Biological Membranes, R. H. Wasserman, Ed. New York, Academic Press, 1963, p. 111

5. Toverud, S. U. The effect of parathyroid hormone and vitamin $\mathrm{D}$ on serum calcium in rats. Acta physiol. scand. 1964, 62, 391.

6. Morgan, A. F., and E. A. Garrison. The effect of vitamin $\mathrm{D}$ and of reaction of diet upon response to parathyroid extract. J. biol. Chem. 1930, 85, 687.

7. Hellman, D., H. R. Baird, and F. C. Bartter. Relationship of maximal tubular phosphate reabsorption to filtration rate in the dog. Amer. J. Physiol. 1964, 207, 89.
8. Fiske, C. H., and Y. SubbaRow. The colorimetric determination of phosphorus. J. biol. Chem. 1925, $66,375$.

9. MacIntyre, I. The flame-spectrophotometric determination of calcium in biological fluids and an isotopic analysis of the errors in the Kramer-Tisdall procedure. Biochem. J. 1957, 67, 164.

10. Prockop, D. J., and S. Udenfriend. A specific method for the analysis of hydroxyproline in tissues and urine. Analyt. Biochem. 1960, 1, 228.

11. Snedecor, G. Statistical Methods, 5th ed. Ames, Iowa, Iowa State College Press, 1965.

12. Walser, M., D. G. Davidson, and J. Orloff. The renal clearance of alkali-stable inulin. J. clin. Invest. $1955,34,1520$.

13. King, E. J., and A. R. Armstrong. A convenient method for determining serum and bile phosphatase activity. Canad. med. Ass. J. 1934, 31, 376.

14. Shue, G. M., L. Friedman, and C. D. Tolle. An improvement in the vitamin $\mathrm{D}$ line test. Analyt. Chem. 1952, 24, 1841.

15. $\mathrm{Li}, \mathrm{J}$. C. R. Introduction to Statistical Inference. Ann Arbor, Edwards Brothers, 1957, pp. 87-104.

16. Aurbach, G. D. Isolation of parathyroid hormone after extraction with phenol. J. biol. Chem. 1959, 234, 3179.

17. Albright, F., and E. C. Reifenstein, Jr. The Parathyroid Glands and Metabolic Bone Disease. Baltimore, Williams \& Wilkins, 1948.

18. Barnicot, N. A. The local action of the parathyroid and other tissues on bone in intracerebral grafts. J. Anat. (Lond.) 1948, 82, 233.

19. Raisz, L. G., W. Y. W. Au, and J. Tepperman. Effect of changes in parathyroid activity on bone metabolism in vitro. Endocrinology 1961, 68, 783.

20. Munson, P. L. Recent advances in parathyroid hormone research. Fed. Proc. 1960, 19, 593.

21. DeLuca, H. F., G. W. Engstrom, and H. Rasmussen. The action of vitamin $\mathrm{D}$ and parathyroid hormone in vitro on calcium uptake and release by kidney mitochondria. Proc. nat. Acad. Sci. (Wash.) 1962, 48, 1604.

22. Munson, P. L., P. F. Hirsch, and A. H. Tashjian, Jr. Parathyroid gland. Ann. Rev. Physiol. 1963, 25, 325.

23. Prockop, D. J. Isotopic studies on collagen degradation and the urine excretion of hydroxyproline. J. clin. Invest. 1964, 43, 453.

24. Stern, B. D., G. L. Mechanic, M. J. Glimcher, and P. Goldhaber. The resorption of bone collagen in tissue culture. Biochem. biophys. Res. Commun. 1963, 13, 137.

25. Walker, D. G., C. M. Lapiere, and J. Gross. A collagenolytic factor in rat bone promoted by parathyroid extract. Biochem. biophys. Res. Commun. 1964, 15, 397.

26. Keiser, H. R., J. R. Gill, Jr., A. Sjoerdsma, and F. C. Bartter. Relation between urinary hydroxyproline and parathyroid function. J. clin. Invest. 1964, 43, 1073. 